\title{
RESENSI BUKU \\ Memperbincangkan Dialog Fotografi dan Sastra dalam 13 Keping
}

\author{
Daru Tunggul Aji \\ Program Studi Desain Komunikasi Visual \\ Fakultas Seni Rupa ISI Yogyakarta \\ daruaji19@gmail.com
}

\begin{tabular}{|l|l|}
\hline Judul & $\begin{array}{l}\text { Estetika Banal dan } \\
\text { Spritualisme Kritis; Dialog } \\
\text { Fotografi dan Sastra dalam 13 } \\
\text { Keping }\end{array}$ \\
\hline Penulis & Erik Prasetya dan Ayu Utami \\
\hline Seri Buku & Fotografi \\
\hline Penerbit & $\begin{array}{l}\text { Kepustakaan Populer } \\
\text { Gramedia, Jakarta }\end{array}$ \\
\hline Tahun & 2015 \\
\hline ISBN & - \\
\hline Tebal buku & vi+ 70 Halaman \\
\hline Harga & - \\
\hline
\end{tabular}

Ketika budaya dan media mulai ramai diperbincangkan -didiskusikan- sejak beberapa dekade lalu, fotografi tak mau ketinggalan. Sebagai bagian dari budaya (visual), fotografi mulai menarik perhatian. Contoh paling gamblang adalah foto pada sampul majalah Paris Match yang diulas oleh Barthes. Kita sama-sama meyakini bahwa foto bukanlah sesuatu yang netral dan alamiah, ia politis. Fotografi bukan saja menarik untuk diperbincangkan dalam ranah fotografi itu sendiri, namun fotografi juga membuka peluang untuk dipertautkan dan diperbincangkan melalui disiplin-disiplin keilmuan yang lain.

Buku ini cukup menarik sebagai sebuah dialog, meski pada bagian awal sudah ada ramburambu yang mengatakan bahwa buku ini bisa dibaca secara terpisah, artinya "tidak saling" terkait, tapi juga bisa sebagai dialog yang saling bertautan. Melalui Estetika Banal dan Spritualisme Kritis; Dialog Fotografi dan Sastra dalam 13 Keping (2015), Erik Prasetya dan Ayu 
Utami coba urun rembug dalam wilayah wacana (visual) kritis. Mereka coba memperbincangkan kedalaman fotografi secara etis maupun estetis.

Ketika fotografi hanya mengejar kualitas dan kuantitas estetis maka posisi etis menjadi sesuatu yang menarik untuk terus dibahasakan sekaligus dipertanyakan. Sebagai sebuah dialog, Erik dan Ayu saling bersautan dalam memberikan gagasan. Keresahan atas sesuatu yang dramatis namun kadangkala dikatakan sebagai karya yang menarik dan "bernilai". Fotografi memang politis, ia mampu mereduksi keluguan seseorang pemotret maupun yang terpotret. Hubungan antara fotografer dengan mereka yang difoto tidak inosen (lagi). Ada kesadaran memandang dan dipandang sehingga politik visual bekerja di dalamnya. Menurutnya, fotografi telah menjadi model pengetahuan. Fotografer jadi tak lugu lagi. Ia memburu estetika. Begitu pula, setelah mengetahui implikasi dari fotografi, objek foto menjadi tidak lugu lagi (hlm. 14)

Melalui kamera, fotografi berperan dalam upaya menghadirkan sang liyan. Fotografi secara mekanis telah menciptakan relasi antara fotografer dengan objek foto. Tak berlebihan, ketika Erik mendampingi Sebastio Salgado memotret di Indonesia, dalam rangka proyek Exodus (1996) Erik mendengar orang-orang Cilincing, yang waktu itu begitu miskin, menyindir dalam bahasa jawa, "seneng, wis motret awake sing kere" (senang, sudah motret kami yang miskin) dalam sindiran itu terkandung kesadaran tentang kelas yang berbeda, barangkali juga warna kulit yang berbeda, serta pengetahuan bahwa kemiskinan memberi kenikmatan bagi kelas atas yang menontonnya. (hlm. 6)

Sampai pada titik ini, problem etis dalam fotografi mulai nampak. Bahwasanya fotografi berusaha mengkonstruksi secara dramatis apa yang orang lain pahami sebagai kemiskinan dan penderitaan dalam kemasan yang artistik. Atas nama industri dan keindahan, fotografi melakukan komodifikasi atas objek-objeknya. "Mungkin ini kutukan dalam fotografi", begitu kata Erik. Dari hal tersebut, lantas Ayu mencoba membuka perbincangan lebih dalam dengan sebuah pertanyaan: apakah keindahan itu sehingga kita lupa pada ketidakadilan?

Erik menyadari bahwa dalam beberapa hal fotografi terjebak dalam dikotomi subjek-objek, yang dipertajam oleh masalah-masalah sosial yang lain seperti -misalnya- persoalan kelas dan gender. Mengingat dikotomi tersebut susah dipisahkan bahkan "didamaikan” antara yang satu dan yang lainnya, maka Erik mencoba mengambil jalan tengan dalam rangka meminimalisir hal tersebut. Beberapa langkah yang ia pilih; (1) memotret masyarakat yang merupakan bukan sang liyan baginya, apapun masyarakat itu, sejauh bisa dengan jujur dan wajar mengidentifikasikan 
diri sebagai bagiannya; (2) memotret tanpa penugasan dan tanpa deadline; (3) Ia meyakini apa yang disebut oleh Ayu sebagai “iman” dalam bahasa. Kepercayaan bahwa di luar sana ada makna yang bisa ditangkap kamera, hal inilah yang membuatnya setia bolak-balik memotret di tempat yang sama. (hlm. 19)

Sebagai sebuah dialog, tentu saja akan memunculkan dialog-dialog berikutnya, termasuk uneg-uneg. Beberapa langkah yang ditawarkan Erik cukup menarik namun terasa mengganjal, setidaknya pada poin pertama. Bukankah ketika kita memotret kita sudah melakukan konstruksi terhadap objek foto?, dengan kata lain kecenderungan untuk "menciptakan" sang liyan akan terbuka. Dalam Camera Lucida Barthes pernah berujar bahwa ketika difoto, ia-dalam hal ini Barthes mencontohkan dirinya sendiri-berpose dan membuat tubuh lain bagi dirinya sendiri, karena antara diri dan citra dirinya diceraikan oleh fotografi. Atau dengan kata lain ia mengalami ketidakontentikan. Atau bisa dikatakan, seperti kata Erik sebelumnya: menjadi tidak lugu lagi.

Bahasan dalam buku ini menghadirkan wacana baru, yakni estetika banal. Bagi saya ini menarik, dalam apa yang disebut sebagai estetika banal, fotografer mencoba mencari pendekatan yang membuatnya tetap sadar dan ingat atas problem-problem baik etis maupun politis. Sedang Ayu mencoba mengambil spritualisme kritis sebagai model penulisan juga sebagai model proses menulis yang di dalamnya tumbuh kesadaran untuk tetap mengusahakan makna. Dalam salah satu bagian buku ini, Ayu menuturkan bahwa foto-foto Erik sebagai: menangkap makna sebelum konvensi. Hal tersebut mirip dengan apa yang terjadi pada puisi, maupun musik kontemporer. Menurutnya seni (bisa) mengingatkan kita kembali pada "makna sebelum konvensi”. Ayu menyebutnya sebagai spirit, dan dari sinilah istilah spiritualisme kritis berangkat. Istilah tersebut (spiritualisme kritis) pertama kali muncul dalam novelnya yang berjudul "Bilangan Fu", melalui tokoh Parang Jati.

Estetika banal tidak lahir begitu saja. Ia hadir dari pengalaman Erik setelah sekian lama memotret jalanan. Kredo estetika banal adalah mencoba melihat keindahan dengan kriteria yang lebih luas. Terbuka pada estetika yang belum dirumuskan. Percaya ada momen-momen indah pada yang sehari-hari dan mencoba merekamnya, mencoba menangkap kewajaran, sehingga tidak menyutradari atau memprovokasi. Dan selalu mempertanyakan kembali hubungan subjekobjek (hlm 25). 
"dan selalu mempertanyakan kembali hubungan subjek-objek", ini menarik, artinya Erik bukan saja memberikan tawaran dari segi praktik bagaimana posisi fotografi dan fotografer dalam memotret, namun juga tetap berusaha kritis dalam mempertanyakan hubungan (subjekobjek) tersebut.

Hubungan antara subjek-objek, fotografer-objek foto, bukanlah hubungan yang setara. Meski tidak menutup kemungkinan hadirnya hubungan yang resiprokal antar keduanya. Fotografi tak bisa dilepaskan dari wacana yang melingkupinya. Ada hubungan "saling memandang", ada strategi "mengada" yang politis, entah bagi fotografer maupun objek foto. Dalam hal ini Erik memberikan contoh kasar dalam hal hunting foto, dimana para fotografer bergerombol dengan memperlakukan manusia lain sebagai objek demi mendapatkan foto yang menarik, sedang contoh yang lebih halus adalah foto jurnalis yang memotret dan memburu estetika, mengonstruksi objek atas nama profesionalisme. 13 keping perbincangan dalam buku ini memberikan suguhan yang menarik. Karena bagaimanapun fotografi tidak pernah dapat dilepaskan dari subjek-objek sebagai pelaku praktik wacana (visual). @daruaji 